\title{
Literatúra - mesto - Bratislava (po roku 1918): stav výskumu a vybrané kontexty Radoslav Passia
}

\author{
PASSIA, R.: Literature - City - Bratislava (After 1918): State of the Art \\ and Selected Contexts \\ SLOVENSKÁ LITERATÚRA, vol. 68, 2021, no. 3, pp. 211-221 \\ DOI: https://doi.org/10.31577/slovlit.2021.68.3.1 \\ ORCID ID: 0000-0001-7045-7901
}

Key words: literature, city, Bratislava, spatial turn, urban studies, geopoetics

At the turn of the $21^{\text {st }}$ century, the spatial turn that took place in various fields of humanities and social sciences could also be observed in literary studies. On the international level, research was inspired by topics and theories from such fields as architecture, urban studies, sociology or anthropology. Slovak literary studies, however, has not been significantly inspired by geopoetics and has not devoted systematic attention to the study of urban locations and motives. This article provides a basic overview of existing research into the representations of urban settings in Slovak literature. It maps topics and methodological background of individual research initiatives with a special focus on literary and artistic representations of Bratislava. The paper also outlines new lines of inquiry, such as the relationship between literary representations of the city in the post-socialist Central Europe and the phenomenon of nostalgia. It also suggests the possibilities of comparative research. With regards to the latter, the author argues that juxtaposing literary representations of Bratislava with representations of urban settings in the literatures of other European "small nations" (Miroslav Hroch) offers more fruitful ground for research than searching for similarities in culturally and geographically closer Hungarian or Czech literature. The article also provides a list of selected literature on the problematics of urban representations in Slovak literature and culture. 
20. storočí bolo mesto v rozličných beletristických, esejistických a publicistických žánroch nielen populárnym, frekventovane zobrazovaným priestorom, ${ }^{\mathbf{1}}$ ale stalo sa aj samostatnou a produktívnou témou. Dlho sa však nevnímalo ako špecifický výskumný problém literárnej vedy. Jason Finch konštatuje, že až po priestorovom obrate („spatial turn“) v nultých a desiatych rokoch 21. storočia sa literárna veda výraznejšie inšpirovala témami a teóriami, ktoré sa od polovice 19. do konca 20. storočia objavovali v myslení o architektúre a sociológii mesta. Dnes je už komunikácia medzi týmito sférami l'udskej kreativity a ich teoretickým reflektovaním vzájomná, „od 70. rokov 20. storočia sa v dielach z oblasti sociológie, architektúry a dizajnu a humánnej geografie dá rozpoznat kultúrny obrat" (Finch 2016:27; preložil R. P.), do urbanistických diskusií vstúpila aj literatúra a „produkty“ iných druhov umenia a kultúry všeobecne.

Podnety humanitných a spoločenských vied, napríklad kultúrnej histórie a sociológie mesta, dnes evidujeme v početných syntetických prácach venovaných architektúre a urbanizmu, v česko-slovenskom kontexte možno uviest' knihy Jiř́ho Hrůzu Svět měst (Hrůza 2014) a Pavla Kalinu Hluboké město. Moderní metropole jako Druhý Řim (Kalina 2019). Podl'a britského bádatel'a Deyana Sudjica sa „dobre vymyslené“, teda úspešné mesto musí nevyhnutne vyrovnat's neustálou rekonfiguráciou a zachovat' si pritom „svojho ducha“ (Sudjic 2017: 263) - práve táto požiadavka spôsobuje, že kultúrne reprezentácie miest, hl'adajúce a udržiavajúce „génia loci“, sa v súčasnosti v takej miere zapájajú a sú zapájané do urbánnych štúdií. Originálnym príspevkom „priestorového obratu“ je teda aj hlbšie porozumenie súvislosti kultúrnej identity, kolektívnej imaginácie a pamäti $\mathrm{s}$ celým konvolútom spoločenských a ekonomických problémov mesta.

Počas „priestorového obratu“ humanitných vied dobiehala postsocialistická čast' strednej Európy ${ }^{2}$ metodologické resty spôsobené politickými zásahmi do slobody bádania pred rokom 1989. V tomto období sa výrazne aktivizovala lokálna kultúrna pamät', opät' sa rozvíjali predtým potlačené kolektívne (miestne, regionálne, etnické) identity ${ }^{3}$ a s týmto procesom bola spojená aj vlna nostalgie, ktorú rozsiahlo reflektovali beletria, film a iné druhy umenia a následne aj odborná literatúra. ${ }^{4} \mathrm{~V}$ niektorých príbuzných disciplínach sa mesto ako výskumný problém (často s nostalgickým odkazom na jeho stratenú krásu, súdržnost'a „mestskost'“) tematizovalo častejšie, napríklad v kultúrnej histórii, etnológii, umenovede

1 Priestor tu chápem ako východiskovú kategóriu literárneho diela, na ktorej „stoji““ jeho fikčný svet (bližšie napríklad Müller - Šidák 2012: 405-406).

2 K pojmu a diskusiám o strednej Európe po druhej svetovej vojne z historického, geopolitického, kultúrneho a literárneho hladiska bližšie napríklad Trávníček 2009.

3 Klúčovými pojmami mestského kultúrneho aktivizmu sa stali posilňovanie lokálnej identity, obnova dedičstva, multikultúrnost' a hl'adanie spoločných dejín rôznych národov a náboženstiev napríklad prostredníctvom exponovania dejín každodennosti, prekonávanie etnocentrického vnímania mesta prostredníctvom individuálnych (Kollai 2009) a kolektívnych projektov (napríklad slovensko-mad'arská publikácia mladých historikov Remembering the City 2013), ale popularitu získavali aj umelecké projekty zachytávajúce aktuálnu identitu slovenských miest. Príkladom sú knižné fotografické publikácie Illah van Oijenovej Bratislava - mesto na mieru (Van Oijen 2007), Košice - dzivost'v srdci (Van Oijen 2011) alebo časozberné fotografické knihy venované bratislavskej Obchodnej ulici (Stacho 2014, Bartoš 2019).

4 Podl'a Svetlany Boymovej, ktorá fenomén nostalgie analyzuje aj na príklade postsocialistických miest, nostalgický prístup k minulosti pracuje metódou remixu (je teda výberový), ide, okrem iného, o protireakciu na rýchlost' virtuálneho priestoru, v ktorom dnes žijeme - nostalgia je túžbou po celistvosti vo fragmentarizovanom svete (Boym 2001: xiii - xix). 
(v bratislavskom kontexte bližšie napríklad Nižňanský 2011, Vrzgulová - Salner 2020, Kralovič 2014), no v slovenskej literárnej vede priestorový obrat neprebehol a problematika mesta sa objavovala skôr v podobe individuálnych ohlasov a jednotlivých pokusov v rámcoch inak zameraných kolektívnych projektov, respektíve v literárnovedných iniciatívach so slovenskou spoluúčastou v zahraničí (Malura 2011). Isté ohlasy „priestorového obratu“ u nás zneli napríklad v súvislosti s areálovými štúdiami, ktoré v akademickej prevádzke konkurujú komplexnejším profilom absolventa tradičným filologickým, teda užšie zameraným študijným odborom.

Nepríliš intenzívne dianie na poli urbánnych štúdií v slovenskej literárnej vede sa zameriava predovšetkým na reflexiu domácej tvorby a doposial' sa v nej menej reflektovali relevantné práce venované stredoeurópskym mestám, ktoré sa pohybujú na pomedzí viacerých humanitno-spoločenskovedných disciplín. Takými sú napríklad esejistické diela Magická Praha (Praga magica, pôvodne 1973) Angela Mariu Ripellina a Dunaj (Danubio, 1986) Claudia Magrisa, či kultúrnohistorické knihy Viedeň na prelome storočí. Politika a kultúra (Fin-de-siecle Vienna. Politics and Culture, 1981) Carla E. Schorskeho, Budapešt' 1900: Historický portrét mesta a jeho kultúry (Budapest 1900. A Historical Portrait of a City and Its Culture, 1988) Johna Lukacsa alebo Krakovv strednej Európe (Kraków w Europie Środka, 200o) Jaceka Purchlu. Podobne vzniklo viacero metodologicky rôznorodých literárnovedných prác skúmajúcich na konkrétne vymedzenom časovom období a materiáli „obraz“ konkrétneho (stredoeurópskeho) mesta; spomeniem aspoň literárno-antropologické publikácie Citlivé město. Eseje z mytopoetiky Daniely Hodrovej (2006), L'vov. O novom č́taní mesta (Lwów. O odczytywaniu miasta na nowo) Katarzyny Kotyńskej (2015) a Neviditelné mesto. Prešporok/Bratislava v cestopisnej literatúre (2013) Jozefa Tancera. Spoločným menovatel'om týchto prác je interdisciplinárny pohl'ad na problematiku obrazu mesta v literatúre inšpirovaný antropológiou, kultúrnymi štúdiami, semiotikou a imagológiou. Funkciu úvodu do problematiky vztahu literárneho diela a urbánneho prostredia a náčrtu jednotlivých teoretických prístupov v česko-slovenskom kontexte aktuálne plní predovšetkým monografia Joanny Derdowskej Kmitavá mozaika. Městský prostor a literární dílo (2011), filozoficko-antropologický vstup do problematiky umožňuje kniha Oliviera Mongina Urbánní situace. Městov čase globalizace (2017), v slovenskom prostredí sa vzájomným prepojeniam filozofického myslenia a mestského priestoru opakovane venoval Miroslav Marcelli (Marcelli 2008, 2011). Príkladom zvýšeného záujmu o výskum mesta v humanitných a spoločenských vedách na Slovensku je špecializovaný vedecký časopis The City and History (pôvodne Mesto a dejiny), ktorý vznikol v roku 2012 na Filozofickej fakulte Univerzity Pavla Jozefa Šafárika v Košiciach.

Napriek tomu, že v slovenskej literárnej vede sa problematike urbánnosti doposial'nevenovala sústavnejšia pozornost', predsa však možno uviest' niekol'ko konkrétnych výsledkov. Už klasickou prácou je štúdia Pavla Minára Mesto v slovenskej medzivojnovej fikcii (predpoklady, pravidlá, kódy a logika produkcie textov) (Minár 1998), v ktorej autor identifikoval antiurbánnu líniu slovenskej modernej prózy. Podobám mestského prostredia v slovenskej modernej próze, napríklad u Janka Jesenského, sa venovala Marcela Mikulová (Mikulová 1998). V literatúre na prelome 19. a 20. storočia sa urbánnou topikou viackrát zaoberala Dana 
214 Hučková (Kršáková 1998, Hučková 2011). Z novších iniciatív treba spomenút aj sumarizačnú štúdiu Reného Bílika Ktematizácii mesta v slovenskej literárnej kultúre v ostravskom zborníku Město (Bílik 2011), kde sa venuje diskusiám nad pastiersko-rolníckym archetypom v slovenskej kultúre a jeho vztahu k mestu. J. Tancer v knihe Neviditelné mesto. Prešporok/Bratislava v cestopisnej literatúre ponúka na základe cudzojazyčnej, najmä staršej literatúry topologický sumár základných motívov a tém, ktoré sformovali obraz Bratislavy v cestovatel'skej literatúre. Vyčleňuje pät'základných tematických oblastí. Pre cestovatel'ov a autorov bedekrov je Bratislava najčastejšie mestom na hranici, zaujíma ich jej panoráma a architektúra, obyvatelia mesta, chápu ju často ako predmestie Viedne, z čoho vyplýva aj častá charakteristika mesta ako miesta pôžitku (Tancer 2013). Autor tohto príspevku si všímal premeny kultúrnej identity a obnovu kolektívnej pamäti na príklade literárnych reprezentácií Košíc (Passia 2014) aj obraz Bratislavy v autobiografických prózach Jána Roznera (Passia 2017). Jaroslav Šrank editoval v roku 2018 zborník na doposial' nespracovanú tému Podoby mesta v slovenskej poézii 20. storočia, kde sa venoval téme mesta v poézii socialistického realizmu (Šrank 2018). V rovnakom zborníku píše Zoltán Rédey o urbánnom charaktere civilnosti v lyrike bratislavských básnikov Ivana Štrpku a Štefana Strážaya (Rédey 2018). Naposledy sa mestu v poézii v súvislosti s poéziou davistov venoval Michal Habaj v kapitole knihy Modernizmus v pohybe (Habaj 2019). Mesto si všíma ako bázu vyrovnávania sa so sociálnou problematikou a v dobovej poézii identifikuje ambivalentný pohyb medzi vitalistickým a nekrofilným vnímaním mesta. Vzt'ah medzi individuálnou autorskou poetikou, dobovou kultúrno-spoločenskou situáciou a zobrazením Bratislavy reflektuje Vladimír Barborík v štúdii o Dušanovi Krausovi (Barborík 2020). Kolektívna publikácia Kontakty literatúry (modely - identity - reprezentácie) obsahuje kapitolu Urbanita a identita, ktorá prináša state venované literárnym reprezentáciám mesta na príkladoch z obdobia klasicizmu a biedermeieru (Vojtech 2020), slovenských románov z pražského prostredia v medzivojnovom období (Pátková 2020) a prozaickej a publicistickej knihy Alexandra Križku z medzivojnovej Prahy a Paríža (Passia 2020).

Rozsiahla historiografická literatúra na tému mesta prináša aj témy inšpiratívne pre literárnohistorický výskum. Zástupne možno spomenút publikácie čiastočne venované otázkam reprezentácie mesta: Meštianstvo a občianska spoločnost' na Slovensku 1900 - 1989 (Mannová 1998) a zborník Medzi provinciou a metropolou. Obraz Bratislavy v 19. a 20. storočí (Dudeková 2012). Vel'a podnetov pre interdisciplinárny prístup $\mathrm{k}$ Bratislave dávajú takpovediac materské disciplíny výskumu mesta, teória a dejiny architektúry a urbanizmu. Urbanistický atlas Bratislavy (Žalman 2016) poskytuje klúčové východiskové informácie o urbanistickom vývoji a premenách mesta, jeho vztahoch s užším a so širším okolím. Okrem rozsiahlej mapovej zložky aj textovo stručne formuluje základné vlastnosti sídla, jeho aktuálne problémy a perspektívy. Na podrobný opis sídlisk ako charakteristického prvku mestského priestoru Bratislavy je zameraná publikácia Bratislava. Atlas sídlisk (Moravčíková 2011). Pre pochopenie klúčových priestorových kvalít, urbanizmu aj konkrétnych architektonických diel Bratislavy sú zásadné práce tímu historikov architektúry okolo Henriety Moravčíkovej, Petra Szalaya a Kataríny Haberlandovej. Bratislavu 20. storočia priblížili širšiemu okruhu záujemcov v popularizačných prácach Moderná Bratislava (Szalay a kolektív 2014) a Vojnová 
Bratislava (Szalay a kolektív 2019). Pre tvár Bratislavy 20. storočia aj súčasnosti klúčové témy modernizmu, modernity a modernizácie a ich vzt'ahu k dvom totalitným režimom skúma zborník Modernéa/alebo totalitnév architektúre 20. storočia na Slovensku (Moravčíková 2013). Urbanistickým koncepciám modernej Bratislavy a historickému vývoju niektorých jej klúčových priestorov sa venuje publikácia Bratislava: (ne)plánované mesto (Moravčíková 2020).

Tematický blok v tomto čísle Slovenskej literatúry je prvým pokusom o širšie a systematickejšie zmapovanie literárnych reprezentácií Bratislavy po roku 1918, dve sondy skúmajú problematiku literárnych reprezentácií na materiáli iných stredoeurópskych miest (Vroclav, Praha). Literárnohistorické a teoretické prístupy k téme kombinujú jednotliví autori s rôznorodými podnetmi zo sociológie, z filozofie, historiografie a urbanizmu. Výsledkom sú prevažne analyticko-interpretačné štúdie pohybujúce sa svojím predmetom aj metodológiou na hraniciach literárnej vedy - v priestore geopoetiky, ktorú Elżbieta Rybicka chápe ako výskumnú orientáciu literárnej vedy zameranú na priestor, ale s dôrazom na oba subjekty interakcie, teda na jednej strane na literárnu skúsenost' miesta, na druhej strane zas na aktívnu funkciu miesta v tvarovaní tejto skúsenosti (Rybicka 2014: 93).

Jednotlivé štúdie sú východiskom pre vývinovo-typologickú rekonštrukciu línie „bratislavských textov“. Pokúšajú sa totiž identifikovat' „uzlové body“ tejto interakcie, teda také kvality mestského priestoru Bratislavy, ktoré slovenská literatúra aktívne reflektovala (napríklad základné fyzicko-geografické danosti, sociálno-etnické charakteristiky, procesy kultúrnej apropriácie, klúčové historické udalosti, politické determinanty a podobne). Autorky a autorov však zaujal aj spôsob, akým literárne diela vnikajú do širšej kultúrnej pamäti obyvatelov, akým spôsobom „modelujú“ “ nefikčný priestor mesta a v neposlednom rade ako kategória (mestského) priestoru spoluformuje poetiku jednotlivých textov.

Priestorová konfigurácia v prozaickom diele nemusí byt' nevyhnutne stvárnená explicitne, ale môže mat' aj diskrétne podoby. Pri výskume tematizácií mesta v literatúre môžeme rozlíšit niekol'ko úrovní: najvšeobecnejšiu univerzálnu poetiku mesta, v ktorej sa uplatňujú určité žánre, naratívy, typy postáv a vztahov späté s mestom ako takým. Ďalšou úrovňou je „,poetika“ konkrétneho mesta-Bratislavy, rekonštruovaná vo vývinovo-typologickej perspektíve. Aktuálne bádanie v oblasti literárnych reprezentácií Bratislavy je stále skôr na „spodnej“ úrovni, vo vstupnej fáze, kde rekonštruujeme „materiálovú základňu“, základný korpus textov. Ciel'om výskumu je zachytit' všetky spomenuté úrovne a prostredníctvom „poetiky Bratislavy“ sa posunút' ku koncepčno-teoretickému rámcu pri uvažovaní o vztahu mesta a literatúry. Napríklad súčast'ou všeobecnej poetiky mesta je od obdobia moderny postava flanéra ${ }^{5}$ a chronotop chôdze mestom. Oba motívy môžeme identifikovat'aj vo výrazných prozaických tematizáciách Bratislavy (napríklad Laco a Bratislava Ivana Horvátha, Peši príbeh Pavla Vilikovského, Epizóda'96 Egona Bondyho, reportážno-publicistická Flanérova košel'a Jany Beňovej a iné). Uvedené motívy zároveň presahujú úroveň konkrétnych diel a zarad'ujú tieto prózy do paradigmy všeobecnej poetiky mesta. Podobne z komparatívneho

5 K problematike flanérstva a pohybu v meste bližšie napríklad Mongin 2017:51-71 alebo Derdowska 2011: 59-61. 
výskumu vyplýva, že súčastou všeobecnej poetiky stredoeurópskeho mesta je napríklad jeho hraničnost' a tranzitívnost', ktoré sa stávajú neoddelitel'nou súčastou obrazu Bratislavy v zahraničnej literatúre.

Tematický blok je z časového hl'adiska venovaný obdobiu od vzniku Československa približne po koniec 20. storočia. Mesto vo všeobecnosti ako klúčový priestor politickej, hospodárskej a kultúrnej inovácie bolo však už pred vznikom Československej republiky parciálnou témou diskusií slovenských elít a stalo sa aj „objektom“ literárnych reprezentácií. Strategickým problémom slovenského národného obrodenia v 19. storočí aj na začiatku 20. storočia bola absencia väčšieho mesta, jednoznačného centra národnej politiky a kultúry. Tieto témy sa preniesli do obdobia prvej republiky a implicitne aj explicitne sa premietali do literatúry, ktorá tento problém reflektovala a spolupodielala sa na „diskusiách“.6 Pozícia mesta a najmä vel'komesta (dominantne Prahy a Budapešti) ako pomerne hostilného priestoru uvedomovania si vlastnej národnej identity v konfrontácii s cudzím a neznámym sa po roku 1918 postupne problematizuje a obohacuje o nové polohy. Nie je prekvapujúce, že v medzivojnovom období v súvislosti s mestom výraznejšie ustupuje diskurz spojený s národnou identitou a do hry vstupujú sociálna problematika a otázky kultúrno-politickej orientácie jednotlivca, subjektu v modernom svete. Od tohto času môžeme v slovenskej kultúre sústavnejšie mapovat' literárne a všeobecne umelecké reprezentácie Bratislavy, mesta ležiaceho na geografickom okraji etnického rozšírenia Slovákov, ktoré dlho ani nemalo ambíciu byt' ich metropolou. Slovenské kultúrne metropoly - a vidno to aj v staršej literatúre - ležali aj predtým mimo Slovenska (Budapešt', Praha, v menšej miere Viedeň).

V tomto zmysle je slovensko-český a slovensko-mad'arský kontext, so zohl'adnením nemeckojazyčnej kultúry habsburskej monarchie, nepochybne nosný a klúčový pre pochopenie umeleckých reprezentácií mesta (zvlášt' Bratislavy) v slovenskej literatúre. Interpretačný kontext apropriačných tendencií slovenského umenia vo vztahu k mestu však nemusí byt' daný len príbuznostou geograficky najbližších kultúr. Je zaujímavé a produktívne uvedomit'si aj paralely v literatúrach „malých" národov, ${ }^{7}$ s ktorými slovenská kultúra nemala sústavnejší kontakt, no ktoré sa podobne výraznejšie etablovali až po prvej svetovej vojne.

Napríklad v klúčcovom ukrajinskom románe dvadsiatych rokov 20. storočia Mesto (Misto) Valeriana Pidmohylného z roku 1928, ktorý sa považuje za prvý mestský román ukrajinskej literatúry, sa riešia dve základné otázky. Prvou je vzt́ah vidieka a mesta na príklade mladých vidiečanov prichádzajúcich žit' a študovat' do Kyjeva - vzniká tu konfrontácia a konflikt so staršou, buržoáznou, usadenou a bohatšie štruktúrovanou, no zároveň petrifikovanou mestskou triedou. V lúbostnom vztahu protagonistu románu, mladého básnika Stepana, k Zoske zohráva potreba hlbšie preniknút' do „vnútorného“ mesta klúčovú úlohu. „Právě její,městskost‘ ho na ní pritahovala, vždyt'stát se pravým městským člověkem bylo hlavním cílem jeho tažení. Bude s ní chodit všude - do divadel, do kin, na večírky, dostane ses ní do městskéspolečnosti, která ho, tojejisté, súctou přijme" (Pidmohylnyj 2019:

6 Bližšie Barborík 2018.

7 Malý národ ,je charakteristika nikoli kvantitativní, nýbrž situační. Označuje evropské národy, které vznikaly v procesu národního hnutí a byly výsledkem jeho úspěchu“ (Hroch 2016: 244). 
188). Rovnako ladené motívy objavovania a osvojovania mesta spojené s láskou viacnásobne nachádzame v Horváthovej novele Laco a Bratislava, ktorá vyšla tiež v roku 1928: „Ked'takto chválil Bratislavu, myslel na Želku, v jeho mysli sa plietli dva pojmy a zlučovali“ (Horváth 2010: 120).

Druhou otázkou je jazykový problém. Ukrajinský jazyk je v mestskom prostredí Kyjeva tej doby príznakovým elementom a prebiehajúca ukrajinizácia nie je len vonkajším historicko-sociálnym dobovým faktom, ale zasahuje do budovania literárnej postavy. Jazyk, vztah k jazyku je jedným z rozhodujúcich tematických elementov románu a súvisí s problematickým procesom premeny postavy z vidiečana na mestského človeka. Všímat' si tu treba aj vytesňované priestory - ukrajinizácia predpokladá východiskovú neukrajinskú bázu, ale o ruštine či iných jazykoch sa v románe explicitne nehovorí. Ide o postupy a reprezentácie ekvivalentné situácii v slovenskej poprevratovej kultúre a jej „poslovenčovacieho“ vzt'ahu k Bratislave.

Litovský spisovatel'a literárny vedec Tomas Venclova píše o vilniuskom mestskom texte spôsobom, ktorý ponúka jasné paralely s Bratislavou a po zmene toponým a etnoným by relevantne vypovedal aj o slovenskej metropole. V oboch prípadoch ide o hlavné mesto relatívne mladej krajiny, ktorá vznikla na základe emancipačných snáh malého európskeho národa a jeho dominantný jazyk (a literatúra) mal v minulosti mesta sekundárnu či terciárnu úlohu:

„Prekrývajú sa tu rôzne rozprávania a kultúrne diskurzy, na prvotnom mytologickom kmeni rastú nepodobné, konkurenčné mýty, dokonca aj národná identifikácia mnohých obyvatel'ov Vilniusu je dost'komplikovaná,jedna a tá istá osoba môže patrit' do viacerých kultúr súčasne (čo navyše často vedie k odcudzeniu, vnútorným konfliktom, bolestivým zážitkom vol'by). Ako poznamenal Miłosz, Vilniusan nie je Litovčan, ani Poliak, ani Bielorus. [...] Možno najviac sa Vilnius vyznačuje tým, že toto mesto je takmer vždy predmetom nostalgie“ (Venclova 2009; preložil R. P.).

Tieto príklady z literatúr stredovýchodnej Európy naznačujú, že typologické a tematologické paralely slovenskej kultúrnej apropriácie mesta treba hl'adat' aj v kontextoch „malých“ národov, teda zvlášt' tých, u ktorých sa emancipačný proces zavŕšil až v priebehu 20. storočia.

Samostatnou výskumnou oblast'ou, ktorú predložený tematický blok nezachytáva a nateraz ostáva otvorená d'alšiemu výskumu, sú literárne reprezentácie mesta v spomienkovo-memoárovom žánri, pokial'ide o Bratislavu napríklad u J. Roznera (Rozner 2010, 2011), Žo Langerovej (Langerová 2008), Vladimíra Reisela (Reisel 2017), Františka Hečku a Márie Jančovej (Hečko - Jančová 2011) či iných. V období po roku 2000 vzniklo aj niekol'ko pokusov zmapovat' niektoré slovenské mestá formou literárnej eseje, reportáže, bedekra a antológie textov, napríklad Prešov (Petraško 2015), Košice (Šimko 2013), Bratislavu (Sako-Hoess 2017, Beňová 2020), beletristické, esejistické a publicistické texty o viac ako dvoch desiatkach slovenských miest zhŕňa antológia Moje mesto (2014).

Bratislava bola v 20. storočí pre slovenskú kultúru osvojovaným mestským priestorom a tento proces je v literárnych obrazoch mesta dobre identifikovatel'ný. Predbežný výskum potvrdzuje, že literárne reprezentácie daný proces špecificky 
218 reflektovali, a hoci motivika objavovania a osvojovania si mesta nie je charakteristická len pre medzivojnovú literatúru, vo vztahu k Bratislave v nej v tomto období dominuje. Naopak, Bratislava vo svojej „samozrejmosti“, neexponovaná ako objekt kolektívnej (etnickej, neskôr triednej) apropriácie, sa v slovenskej literatúre objavuje významnejšie až od šest'desiatych rokov 20. storočia. Bratislavská literatúra je však doposial'nezviditel'nený fenomén a výsledky nášho aktuálneho výskumu azda prispejú k jeho sprítomneniu v literárnej vede aj kolektívnej imaginácii.

Štúdia je výstupom grantového projektu VEGA 2/0069/19 „Geopoetika“ Bratislavy: reprezentácie mesta v slovenskej literatúre po roku 1918. Zodpovedný riešitel': Mgr. Radoslav Passia, Ph.D. Doba riešenia: 2019-2022.

\section{Pramene}

BARTOŠ, Juraj, 2019. Svedectvo doby. Obchodná ulica. Bratislava:Zum Zum production. ISBN 978-80-89896-08-0.

BEŇOVÁ, Jana, 2020. Flanérova košel'a. 8 1⁄2 bratislavských ulíc. Bratislava: OZ BRAK. ISBN 978-80-89921-32-4.

HEČKO, Ján-JANČOVÁ, Mária, 2011. Denníky 1938-1960. Bratislava: Marenčin PT. ISBN 978-80-81140-79-2.

HORVÁTH, Ivan, 2010. Laco a Bratislava (Najjednoduchši príbeh). In HORVÁTH, Ivan. Prózy. Bratislava: Kalligram-Ústav slovenskej literatúry SAV, s. 96-152. ISBN 978-80-8101-371-3.

LANGEROVÁ, Žo, 2015. Vtedy v Bratislave. Môj život s Oskarom L. Bratislava: Marenčin PT. ISBN 978-80-81145-79-7.

Moje mesto, 2014. Zostavili Eugen Gindl a Ján Púček. Ivanka pri Dunaji: F. R. \& G. ISBN 978-80-89499-26-7.

PETRAŠKO, Ludovít, ed., 2015. Hlasy mesta: Literárna čítanka o Prešove. Prešov: Vydavatel'stvo Prešovskej univerzity. ISBN 978-80-555-1449-9.

PIDMOHYLNYJ, Valerjan, 2019. Město. Preklad Miroslav Tomek. Brno: Větrné mlýny. ISBN 978-80-7443-345-0.

REISEL, Vladimír, 2017. Vidím všetky dni. Bratislava: Marenčin PT. ISBN 978-80-81149-03-0. ROZNER, Ján, 2010. Noc po fronte. Bratislava: Marenčin PT. ISBN 978-80-81140-37-2.

ROZNER, Ján, 2011. Výlet na Devín. Bratislava: Marenčin PT. ISBN 978-80-81140-80-8.

SAKO-HOESS, Renata, 2017. Literarischer Reiseführer Pressburg/Bratislava. Potsdam: Deutsches kulturforum östliches Europa. ISBN 978-3-936168-68-6.

STACHO, Lubo, 2014. Obchodná 1984 - 2014. Bratislava: Slovart - O.K.O. ISBN 978-8088805-14-4.

ŠIMKO, Dušan, 2013. Košice-Kaschau: Ein Reise- und Lesebuch. Wuppertal: Arco. ISBN 9783-938375-50-1.

VAN OIJEN, Illah, 2007. Bratislava - mesto na mieru: Urban Landscapes of Bratislava. Bratislava: Slovart. ISBN 978-80-808-5589-5.

VAN OIJEN, Illah, 2011. Košice - dzivost'v srdci: Urban Landscapes of Košice. Bratislava: Slovart. ISBN 978-80-556-0209-7.

\section{Všeobecná literatúra}

BARBORÍK, Vladimír, 2018. Hledání centra: slovenská literatura mezi Martinem, Prahou a Bratislavou. In ŠÁMAL, Petr - PAVLÍČEK, Tomáš - BARBORÍK, Vladimír - JANÁČEK, Pavel. Literární kronika první republiky: Události, díla, souvislosti. Praha: Academia - Památník národního písemnictví - Ústav pro českou literaturu AV ČR, v. v. i., s. 50-54. ISBN 978-80-200-2909-6.

BÍLIK, René, 2011. K tematizácii mesta v slovenskej literárnej kultúre: o jednom kultúrnom konštrukte. In MALURA, Jan - TOMÁŠEK, Martin, ed. Město: Vytvárení prostoru v literatuře a výtvarném umění. Ostrava: Filozofická fakulta Ostravské univerzity, s. 46-59. ISBN 978-80-7368-996-4. 
BOGDANOVIĆ, Bogdan, 2002. Mesto a démoni. Bratislava: Vydavatel'stvo Ivan Štefánik. ISBN 80-968189-5-3.

BOGDANOVIĆ, Bogdan, 2005. Sprievodca labyrintom mesta. Bratislava: Type Style. ISBN 80-968189-7-X.

BOYM, Svetlana, 2001. The Future of Nostalgia. New York: Basic Books. ISBN 9780465007080. DERDOWSKA, Joanna, 2011. Kmitavá mozaika: Městský prostor a literární dílo. Př́bram: Pistorius \& Olšanská. ISBN 978-80-87053-57-7.

FERENČUHOVÁ, Slavomíra-HLEDÍKOVÁ, Magdalena-GALČANOVÁ, Lucia-VACKOVÁ, Barbora, ed., 2009. Město: Proměnlivá ne/samozřejmost. Červený Kostelec-Brno: Pavel Mervart - Masarykova univerzita. ISBN 978-80-86818-86-3.

FINCH, Jason, 2016. Modern Urban Theory and the Study of Literature. In TAMBLING, Jeremy, ed. The Palgrave Handbook of Literature and the City. London: Palgrave Macmillan, s. 27-44. ISBN 978-1-137-54910-5.

GAYER, Veronika-OTČENÁŠOVÁ, Slávka-ZAHORÁN, Csaba, ed. 2013. Remembering the City: A Guide Through the Past of Košice. Budapest - Košice: Terra Recognita Alapítvány - UPJŠ v Košiciach. ISBN 978-963-89185-2-9.

HODROVÁ, Daniela a kolektív, 1997. Poetika mist: Kapitoly z literárni tematologie. Jinočany: H \& H. ISBN 978-80-86022-04-8.

HODROVÁ, Daniela, 2006. Citlivé město: Eseje z mytopoetiky. Praha: Akropolis. ISBN 80-86903-31-1.

HROCH, Miroslav, 2016. Hledání souvislostí. Eseje z komparativních dějin Evropy. Praha:SLON. ISBN 978-80-7419-232-6.

HRŮZA, Jiří, 2014. Svět měst. Praha: Academia. ISBN 978-80-200-1808-3.

HUČKOVÁ, Dana [KRŠÁKOVÁ, Dana], 1998. Obraz spoločenského života meštianskych vrstiev v slovenskej literatúre na konci 19. a začiatku 20. storočia. In MANNOVÁ, Elena, ed. Meštianstvo a občianska spoločnost' na Slovensku 1900 - 1989. Bratislava: Academic Electronic Press, s. 93-99. ISBN 80-88880-20-3.

HUČKOVÁ, Dana, 2011. Podoby vel'komesta a malomesta v slovenskej literatúre na prelome 19. a 20. storočia: úvodné poznámky k téme. Slovenská literatúra, roč. 58, č. 6, s. 505-521. ISSN 0037-6973.

KALINA, Pavel, 2019. Hluboké město: Moderní metropole jako Druhý Řim. Praha: Academia. ISBN 978-80-200-2939-3.

KOTYŃSKA, Katarzyna, 2015. Lwów: O odczytywaniu miasta na nowo. Kraków: Międzynarodowe Centrum Kultury. ISBN 978-83-63 463-25-0.

LUKACS, John, 2021. Budapešt' 1900: Historický portrét města a jeho kultury. Praha: Academia. ISBN 978-80-20031-47-1.

MAGRIS, Claudio, 2010. Dunaj:Životopis řeky. Praha: Mladá fronta. ISBN 978-80-20421-18-0.

MALURA, Jan-TOMÁŠEK, Martin, ed., 2011. Město: Vytváření prostoru v literatuře a výtvarném umění. Ostrava: Filozofická fakulta Ostravské univerzity. ISBN 978-80-7368-996-4.

MALURA, Jan-TOMÁŠEK, Martin, ed., 2012. Krajina: Vytváření prostoru v literatuře a výtvarném umění. Ostrava: Filozofická fakulta Ostravské univerzity. ISBN 978-80-7464-176-3.

MANNOVÁ, Elena, ed., 1998. Meštianstvo a občianska spoločnost'na Slovensku 1900 - 1989. Bratislava: Academic Electronic Press. ISBN 80-88880-20-3.

MIKULOVÁ, Marcela, 1998. Mestský živel (u) Janka Jesenského. In MANNOVÁ, Elena, ed. Meštianstvo a občianska spoločnost' na Slovensku 1900 - 1989. Bratislava: Academic Electronic Press, s. 101-110. ISBN 80-88880-20-3.

MINÁR, Pavol, 1998. Mesto v slovenskej medzivojnovej fikcii (predpoklady, pravidlá, kódy a logika produkcie textov). In MANNOVÁ, Elena, ed. Meštianstvo a občianska spoločnost' na Slovensku 1900 - 1989. Bratislava: Academic Electronic Press, s. 111-135. ISBN 80-88880-20-3.

MONGIN, Olivier, 2017. Urbánnísituace. Město v čase globalizace. Přeložila Edita Wolf. Praha: Karolinum. ISBN 978-80-246-3442-5.

MÜLLER, Richard - ŠIDÁK, Pavel, 2012. Slovník novějši literární teorie: glosář pojmů. Praha: Nakladatelství Academia. ISBN 978-80-200-2048-2.

PASSIA, Radoslav, 2014. Na hranici: Slovenská literatúra a východokarpatský hraničný areál. Levoča: Modrý Peter. ISBN 978-80-89545-30-8.

PASSIA, Radoslav, 2020. Alexander Križka a mesto v jeho prózach z dvadsiatych rokov 20. storočia. In BYSTRZAK, Magdalena - PASSIA, Radoslav - TARANENKOVÁ, Ivana, ed. Kontakty literatúry. Modely, identity, reprezentácie. Bratislava: Veda, s. 277-290. ISBN 978-80-224-1856-0. 
PÁTKOVÁ, Jana: Obraz Prahy v zapomenutých slovenských románech meziválečného období. In BYSTRZAK, Magdalena-PASSIA, Radoslav-TARANENKOVÁ, Ivana, ed. Kontakty literatúry. Modely, identity, reprezentácie. Bratislava: Veda, s. 259-275. ISBN 978-80-224-1856-0.

PURCHLA, Jacek, 2000. Kraków w Europie Środka. Kraków: Międzynarodowe Centrum Kultury. ISBN 83-85739-76-9.

RIPELLINO, Angelo Maria, 2009. Magická Praha. Praha: Argo. ISBN 978-80-257-0191-1. RYBICKA, Elżbieta, 2014. Geopoetyka. Przestrzeń i miejsce we wspótczesnych teoriach i praktykach literackich. Kraków: Universitas. ISBN 97883-242-3041-9.

SCHORSKE, Carl E., 1981. Fin-de-siècle Vienna:Politics and Culture. New York: Vintage Books. ISBN 0-394-74478-0.

SUDJIC, Deyan, 2017. Jezykmiast. Kraków: Wydawnictwo Karakter. ISBN 978-83-65271-41-9.

SVATOŇ, Vladimír, 2002. Gogolovo symbolické město. In SVATOŇ, Vladimír. $Z$ druhého břehu (Studie a eseje o ruské literatuře). Praha: Torst, s. 217-229. ISBN 80-7215-179-7.

SVATOŇ, Vladimír, 2002. Petrohrad - město helénismu. Konstantin Vaginov. In SVATOŇ, Vladimír. Z druhého břehu (Studie a eseje o ruské literatuře). Praha: Torst, s. 364-372. ISBN 80-7215-179-7.

ŠRANK, Jaroslav, ed., 2018. Podoby mesta v slovenskej poézii 20. storočia. Bratislava: Univerzita Komenského. ISBN 978-80-223-4622-1.

TAMBLING, Jeremy, ed., 2016. The Palgrave Handbook of Literature and the City. London: Palgrave Macmillan. ISBN 978-1-137-54910-5.

TRÁVNÍČEK, Jiří, ed., 2009. Vkleštích dějin. Středni Evropa jako pojem a problém. Brno: Host. ISBN 978-80-7294-323-4.

VOJTECH, Miloslav, 2019. Prvá próza s tematikou mesta v dejinách slovenskej literatúry (Pavel Ján Tomášek - Obchodníci). Slovenčinár, roč. 6, č. 1-2, s. 19-31. ISSN 1339-4908.

VOJTECH, Miloslav, 2020. Polarita urbánneho a rurálneho v literatúre slovenského klasicizmu a biedermeieru. In BYSTRZAK, Magdalena - PASSIA, Radoslav - TARANENKOVÁ, Ivana, ed. Kontakty literatúry. Modely, identity, reprezentácie. Bratislava: Veda, s. 243-257. ISBN 978-80-224-1856-0.

\section{Výberová literatúra zameraná na Bratislavu}

BADŽGOŇOVÁ, Katarína, 2020. Podoby mestského a prírodného prostredia v prózach Máriusa Kopcsaya, Moniky Kompaníkovej a Petra Krištúfka. Slovenská literatúra, roč. 67, č. 2, s. 139-156. ISNN 0037-6973.

BADŽGOŇOVÁ, Katarína, 2020. Petržalský labyrint. In SOUČKOVÁ, Marta, ed. K poetologickým a axiologickým aspektom slovenskej literatúry po roku 2000 VI: zborník materiálov z medzinárodnej vedeckej konferencie, konanej 21. - 22. novembra 2019 na FF PU v Prešove. Prešov: Filozofická fakulta Prešovskej univerzity, s. 122-136. ISBN 978-80-555-2561-7.

BARBORÍK, Vladimír, 2020. Človek v meste (Debut Dušana Krausa Životy unikajúce). Slovenská literatúra, 2020, roč. 67, č. 5, s. 448-466. ISSN 0037-6973.

DUDEKOVÁ, Gabriela, ed., 2012. Medzi provinciou a metropolou:Obraz Bratislavy v 19. a 20. storočí. Bratislava: Historický ústav SAV. ISBN 978-80-89396-21-4.

HORVÁTH, Vladimír, 1990. Bratislavský topografický lexikon. Bratislava: Tatran. ISBN 80222-0229-0.

JENČÍKOVÁ, Eva, 2002. Mesto ako médium modelovej existencie človeka: k toposu mesta v Slobodovom románe Rozum. Slovenská literatúra, roč. 49, č. 1, s. 31-39. ISSN 0037-6973.

KRALOVIČ, Ján, 2014. Teritórium ulica: Umenie akcie v mestskom priestore v rokoch 1965 - 1989 na Slovensku. Bratislava: Slovart-VŠVU. ISBN 978-80-89259-85-4.

KOLLAI, István, 2009. A Capital On The Borderland: Bratislava. Budapest: Terra Recognita Alapítvány. ISBN 978-96-306-7444-7.

MARCELLI, Miroslav, 2008. Filozofi v meste. Bratislava: Kalligram. ISBN 978-80-8101-013-2. MARCELLI, Miroslav, 2011. Mesto vo filozofii. Bratislava: Kalligram. ISBN 978-80-8101-400-0. MORAVČÍKOVÁ, Henrieta a kolektív, 2011. Bratislava: atlas sídlisk: [vitajte v panelstory!]. Bratislava: Slovart. ISBN 978-80-556-0478-7.

MORAVČÍKOVÁ, Henrieta, 2013. Moderné a/alebo totalitnév architektúre 20. storočia na Slovensku. Bratislava: Slovart. ISBN 978-80-556-1056-6.

MORAVČÍKOVÁ, Henrieta-SZALAY, Peter-HABERLANDOVÁ, Katarína-KRIŠTEKOVÁ, Laura-BOČKOVÁ, Monika, 2020. Bratislava (ne)plánované mesto. Bratislava (un)planned city. Bratislava: Slovart. ISBN 978-80-556-4696-1. 
MOSKWIN, Andrej, ed., 2016. Bratystawa - miasto na skrzyżowaniu kultur / Bratislava - mesto na križovatke kultúr. Warszawa: Instytut Słowacki w Warszawie - Katedra Studiów Interkulturowych Europy Šrodkowo-Wschodniej Uniwersytetu Warszawskiego. ISBN 9788394563042.

NIŽŇANSKÝ, Eduard a kolektív, 2011. Stratené mesto. Bratislava: Marenčin PT. ISBN 978-80-8114-108-9.

PASSIA, Radoslav, 2017. Prózy Jána Roznera a Bratislava (spisovatel'- autobiografia-mesto). Slovenská literatúra, roč. 64, č. 2, s. 104-117. ISSN 0037-6973.

RÉDEY, Zoltán, 2018. Dve polohy „urbánnej civilnosti“v lyrike - podoby mesta v poézii Š. Strážaya a I. Štrpku. In ŠRANK, Jaroslav. Podoby mesta v slovenskej poézii 20. storočia. Bratislava: Univerzita Komenského, s. 119-143. ISBN 978-80-223-4622-1.

SABATOS, Charles, 2020. Bratislava as a cultural borderland in the Danubian narratives of Patrick Leigh Fermor and Claudio Magris. In World Literature Studies, vol. 12, č. 4, s. 3-19. ISSN 1337-9275.

SZALAY, Peter a kolektív, 2014. Moderná Bratislava 1918 - 1939. Bratislava: Marenčin PT. ISBN 978-80-8114-327-4.

SZALAY, Peter a kolektív, 2019. Vojnová Bratislava 1939 - 1945. Bratislava: Marenčin PT. ISBN 978-80-569-0131-1.

TANCER, Jozef, 2013. Neviditel'né mesto: Prešporok/Bratislava v cestopisnej literatúre. Bratislava: Kalligram.

TANCER, Jozef, 2016. Rozviazané jazyky: ako sme hovorili vstarej Bratislave. Bratislava: Slovart. ISBN 978-80-556-2458-7.

VRZGULOVÁ, Monika - SALNER, Peter, ed., 2020. Dvojrozhovor o pamäti, histórii a meste. Bratislava: Marenčin PT. ISBN 978-80-569-0676-7.

ŽALMAN, Peter, 2016. Urbanistický atlas Bratislavy. Bratislava: GDA VISUAL, s. r. o. ISBN 978-80-972542-0-9.

\section{Internetové zdroje}

VENCLOVA, Tomas, 2009. Wilno jako obiekt nostalgii. In Eurozine [online], 6. 10. 2009. Dostupné z: https://www.eurozine.com/wilno-jako-obiekt-nostalgii/.Citované 18. 3.2021.

Mgr. Radoslav Passia, Ph.D.

Ústav slovenskej literatúry SAV

Dúbravská cesta 9

84104 Bratislava

Slovenská republika

E-mail: Radoslav.Passia@savba.sk 